\title{
Aktivitas Antibakteri Ekstrak Karang Lunak Sarcophyton sp. yang Difragmentasi dan Tidak Difragmentasi dari Perairan Pulau Pramuka, Kepulauan Seribu, Jakarta
}

\author{
Antibacterial Activities of Fragmented and Non Fragmented Extracts of Soft Coral \\ Sarcophyton sp. from Pramuka Island, Kepulauan Seribu, Jakarta \\ Mujizat Kawaroe $^{1 *}$, Dedi Soedarma ${ }^{1}$, Hefni Effendi², Tati Nurhayati² dan Safrina Dyah \\ Hardiningtyas ${ }^{3}$
}

\author{
${ }^{1}$ Departemen Ilmu dan Teknologi Kelautan, Fakultas Perikanan dan Ilmu Kelautan IPB Bogor, 16680 \\ ${ }^{2}$ Departemen Manajemen Sumberdaya Perairan, Fakultas Perikanan dan Ilmu Kelautan IPB Bogor, 16680 \\ ${ }^{3}$ Departemen Teknologi Hasil Perairan, Fakultas Perikanan dan Ilmu Kelautan IPB Bogor, 16680 \\ E-mail: mujizat@ipb.ac.id*Penulis untuk korespondensi
}

\begin{abstract}
Fragmented and non-fragmented soft corals showed antibacterial activities. Soft corals were gradually extracted using methanol, ethyl acetate, and hexane. Crude extract of the samples was tested its antibacterial activity, Minimun Inhibitory Concentration, toxicity (Brine Shrimp Lethality Test method), and phytochemicals. Overall, the antibacterial activity of crude extract of non-fragmented soft coral Sarcophyton sp. was higher than the crude extract of fragmented soft coral Sarcophyton sp. Crude ethyl acetate extract showed higher antibacterial activities. The ethyl acetate crude extract of non-fragmented soft coral Sarcophyton sp. is able to inhibit all tested bacteria is $E$. coli, $S$. aureus, $P$. aeruginosa and B.cereus, while the ethyl acetate crude extract of fragmented Sarcophyton $s p$. is unable to inhibit bacteria $P$. aeruginosa. Minimum inhibitory concentration extracts of non-fragmented Sarcophyton sp. in range $240-480 \mu \mathrm{g} / \mathrm{disc}$. The 24-h LC $\mathrm{LC}_{50}$ extracts of fragmented and non-fragmented Sarcophyton sp. for Artemia salina were $149.50 \mathrm{ppm}$ and $45.15 \mathrm{ppm}$, respectively. Bioactive compounds of fragmented and nonfragmented Sarcophyton sp. extract are steroid, flavonoid and alkaloid.
\end{abstract}

Key words: Bioactive compound, antibacterial, soft coral, Sarcophyton sp.

\section{Abstrak}

Karang lunak yang difragmentasi dan tidak difragmentasi menunjukkan aktivitas antibakteri. Karang lunak diekstrak secara bertingkat menggunakan pelarut metanol, etil asetat, dan heksana. Ekstrak kasar dari sampel dilakukan pengujian aktivitas antibakteri, Minimum Inhibitory Concentration, toksisitas (metode Brine Shrimp Lethality Test), dan fitokimia. Secara keseluruhan, aktivitas antibakteri ekstrak kasar karang lunak Sarcophyton sp. yang tidak difragmentasi lebih tinggi dibandingkan dengan ekstrak kasar karang lunak Sarcophyton sp. yang difragmentasi. Ekstrak kasar etil asetat menunjukkan aktivitas antibakteri yang lebih tinggi. Ekstrak kasar etil asetat karang lunak Sarcophyton sp. yang tidak difragmentasi dapat menghambat semua bakteri uji yaitu E.coli, $S$. aureus, P. aeruginosa, dan B.cereus., sedangkan ekstrak kasar etil asetat Sarcophyton sp. yang difragmentasi tidak dapat menghambat bakteri P.aeruginosa. Minimum inhibitory concentration dari ekstrak Sarcophyton sp. berkisar 240-480 $\mu \mathrm{g} /$ disk. Nilai LC $\mathrm{C}_{50}$ dari ekstrak etil asetat Sarcophyton sp. yang difragmentasi dan tidak difragmentasi, masing-masing sebesar 149,50 ppm dan 45,15 ppm. Komponen bioaktif pada ekstrak etil asetat Sarcophyton sp. yang difragmentasi dan tidak difragmentasi adalah steroid, flavonoid, dan alkaloid.

Kata kunci: Karang lunak, ekstrak, antibakteri, komponen bioaktif 


\section{Pendahuluan}

Sarcophyton sp. merupakan salah satu jenis karang lunak yang memproduksi senyawa kimia alami dan dikenal dengan istilah natural product. Senyawa kimia alami tersebut berpotensi sebagai sumber obat alami. Hasil penelitian yang dilakukan Badria et al., (1998) dan Sawant et al., (2006) menunjukkan bahwa senyawa kimia aktif yang terdapat pada karang lunak Sarcophyton sp. menunjukkan aktivitas sebagai antibakteri, antifungi, antitumor, neurotoksik, dan anti-inflamantori yang bermanfaat bagi industri farmasi.

Pemanfaatan senyawa bioaktif karang lunak yang kini dilakukan masih berasal dari alam sehingga perlu suatu upaya budidaya untuk mencegah eksploitasi organisme tersebut (over fishing) (Astuti et al., 2003). Salah satu upaya yang dapat dilakukan untuk memenuhi kebutuhan bahan baku obat tanpa mengambil dari alam adalah melakukan budidaya dengan metode fragmentasi karang (Soedharma et al., 2005).

Fragmentasi karang dilakukan dengan cara memotong koloni induk menjadi kepingankepingan kecil (fragmen), kemudian diletakkan pada substrat. Fragmen tersebut akan menempel pada substrat dan berkembang menjadi koloni yang baru (Smith dan Hughes, 1999). Beberapa tahun terakhir para peneliti di Institut Pertanian Bogor telah berhasil melakukan fragmentasi karang lunak jenis Sarcophyton sp, Sinularia sp., dan Lobophytum sp. pada dua kedalaman yang berbeda (3 dan $12 \mathrm{~m}$ ) di Perairan Pulau Pramuka, Kepulauan Seribu, Jakarta.

Penelitian mengenai aktivitas antibakteri ekstrak dari karang lunak jenis Sinularia sp. dan Lobophytum sp. hasil fragmentasi pada dua kedalaman yang berbeda di Perairan Pulau Pramuka, Kepulauan Seribu sudah dilakukan oleh Priyatmoko (2008) dan Triyuliati (2009). Berdasarkan hasil penelitian tersebut diketahui bahwa karang lunak hasil fragmentasi di kedalaman $10 \mathrm{~m}$ memiliki aktivitas antibakteri yang lebih baik dibandingkan dengan karang lunak hasil fragmentasi di kedalaman $3 \mathrm{~m}$. Ekstrak karang lunak hasil fragmentasi di kedalaman $10 \mathrm{~m}$ dapat menghambat bakteri Escherichia coli dan Staphylococcus aureus.
Karang lunak jenis Sarcophyton sp. telah berhasil difragmentasi dan banyak tersebar di perairan Kepulauan Seribu. Efektifitas aktivitas antibakteri karang lunak Sarcophyton sp. hasil fragmentasi dan Sarcophyton sp. yang tumbuh secara alami masih belum diketahui sehingga perlu dilakukan penelitian dan pengkajian tentang aktivitas antibakteri ekstrak karang lunak Sarcophyton sp. yang difragmentasi dan tidak difragmentasi di Perairan Pulau Pramuka, Kepulauan Seribu, Jakarta.

\section{Metode Penelitian}

Penelitian ini dilakukan pada bulan April-Juli 2009 di Area Perlindungan Laut Perairan Pulau Pramuka, Kepulauan Seribu, dan di Laboratorium Mikrobiologi Hasil Perairan, IPB Bogor. Alat-alat yang digunakan pada penelitian ini antara lain SCUBA, timbangan, cool box, es, vaccum rotary evaporator, kertas saring (Whatman 40), laminar, refrigerator, cawan petri, paper disc, pipet mikro, autoklaf, kompor listrik, alat gelas, inkubator, dan spektrofotometer lampu.

Bahan-bahan yang digunakan adalah sampel karang lunak Sarcophyton sp., metanol, etil asetat, heksana, biakan bakteri uji (E. coli, $S$. aureus, $P$. aeruginosa, dan $B$. cereus), medium Nutrient broth, medium agar Muller Hinton, air laut steril, larva A. salina, asam sulfat pekat $2 \mathrm{~N}$, reagen dragendroff, reagen meyer, reagen wagner, kloroform, anhidria asetat, asam sulfat pekat, magnesium, amil alkohol, alkohol, $\mathrm{HCl} 2$ $\mathrm{N}$, etanol $70 \%, \mathrm{FeCl}_{3} 5 \%$, perekasi molisch, reagen benedict, reagen biuret dan larutan ninhidrin $0,1 \%$.

\section{Pengambilan Sampel Karang Lunak Sarcophyton sp.}

Karang lunak Sarcophyton sp. yang difragmentasi dan tidak difragmentasi dikoleksi dari perairan Pulau Pramuka, Kepulauan Seribu pada koordinat $06^{\circ} 45^{\prime}, 6^{\prime \prime}$ LS dan $106^{\circ} 32^{\prime}, 45^{\prime}$, BT.

\section{Ekstraksi Senyawa Bioaktif Sarcophyton sp.}

Ekstraksi komponen bioaktif pada Sarcophyton sp. menggunakan metode modifikasi Huda et al., (2009). Pelarut organik yang digunakan dalam ekstraksi yaitu metanol, 
etil asetat, dan heksana. Perbandingan antara sampel dan tiap-tiap pelarut adalah 1:2. Sampel karang lunak Sarcophyton sp. sebanyak $100 \mathrm{~g}$ dipotong kecil-kecil lalu dilakukan maserasi selama 24 jam. Maserasi menggunakan pelarut organik dilakukan secara berturut-turut. Hasil maserasi kemudian disaring sehingga diperoleh filtratnya. Seluruh filtrat hasil penyaringan dilakukan evaporasi untuk memisahkan pelarut dari senyawa bioaktif yang terikat pada suhu $37^{\circ} \mathrm{C}$ sehingga didapatkan ekstrak dalam bentuk pasta (cair), disebut sebagai ekstrak kasar.

\section{Uji Akivitas Antibakteri}

Uji ini dilakukan terhadap ekstrak kasar karang lunak Sarcophyton sp. yang difragmentasi dan tidak difragmentasi. Bakteri uji yang digunakan antara lain E. coli, S. aureus, $P$. aeruginosa, dan $B$. cereus. Pengujian aktivitas antibakteri dilakukan dengan metode difusi agar (Kirby-Bauer) menggunakan kertas cakram (paper disc) (Lay, 1994 dalam Noer dan Nurhayati, 2006).

\section{Uji Minimum Inhibitory Concentration}

Uji Minimum Inhibitory concentration (MIC) dilakukan untuk mengetahui konsentrasi minimum dari ekstrak yang terpilih dalam menghambat aktivitas pertumbuhan dari bakteri uji. Uji MIC yang dilakukan sesuai dengan metode Lopez et al., (1993) yang telah dimodofikasi. Pengujian MIC menggunakan metode difusi agar menggunakan kertas cakram (paper disc). Tiap kertas cakram diberi konsentrasi ekstrak yang berbeda-beda dimulai dari konsentrasi rendah sampai tinggi dengan tujuan mengetahui pada konsentrasi berapa bakteri uji dapat terhambat pertumbuhannya (Tabel 1).

\section{Uji Toksisitas}

Tingkat toksisitas suatu bahan dapat diprediksi dengan menggunakan metode Brine Shrimp Lethality Test (BSLT) (Meyer et al., 1982, McLaughlin et al., 1998 dan Carballo et al., 2002). Pada uji ini digunakan larva A. salina sebagai hewan uji. Mula-mula telur A. salina ditetaskan di dalam air laut, setelah 48 jam telur menetas menjadi naupli yang bentuknya seperti berudu. Larva A. salina sebanyak 10 ekor dimasukkan ke dalam tabung reaksi yang telah berisi larutan ekstrak sampel dengan konsentrasi 10, 100 dan 1000 ppm dan ditambahkan air laut sampai volume $5 \mathrm{ml}$. Air laut tanpa pemberian ekstrak (0 ppm) digunakan sebagai kontrol. Setiap perlakuan serta kontrol dibuat tiga kali ulangan. Semua tabung reaksi diinkubasi pada suhu kamar selama 24 jam di bawah penerangan lampu TL 40 watt. Pengamatan dilakukan setelah 24 jam dengan menghitung jumlah $A$. salina yang mati pada tiap konsentrasi. Penentuan harga $\mathrm{LC}_{50}$ (ppm) dilakukan dengan menggunakan analisis probit dan persamaan regresi (Carballo et al., 2002).

\section{Uji Fitokimia}

Identifikasi senyawa kimia yang berperan sebagai antibakteri dalam ekstrak Sarcophyton sp. yang difragmentasi dan tidak difragmentasi dilakukan terhadap senyawa-senyawa, yaitu alkaloid, steroid/triterpenoid, flavonoid, saponin, fenol hidrokuinon, molish, benedict, biuret, dan ninhidrin (Harborne, 1987).

Tabel 1. Konsentrasi ekstrak kasar Sarcophyton sp. dan kloramfenikol (kontrol) pada uji MIC (dalam satuan yang berbeda).

\begin{tabular}{cccc}
\hline $\begin{array}{c}\text { Konsentrasi Ekstrak } \\
\text { Sarcophyton sp. }(\mathbf{p p m})\end{array}$ & $\begin{array}{c}\text { Konsentrasi Ekstrak Sarcophyton sp. } \\
\text { Per Kertas Cakram }(\boldsymbol{\mu g})\end{array}$ & $\begin{array}{c}\text { Konsentrasi } \\
\text { Kloramfenikol (ppm) }\end{array}$ & $\begin{array}{c}\text { Konsentrasi Kloramfenikol } \\
\text { Per Kertas Cakram }(\boldsymbol{\mu g})\end{array}$ \\
\hline 24.000 & 480 & 24.000 & 480 \\
21.000 & 420 & 21.000 & 420 \\
18.000 & 360 & 18.000 & 360 \\
15.000 & 300 & 15.000 & 300 \\
12.000 & 240 & 12.000 & 240 \\
9.000 & 180 & 9.000 & 180 \\
2.000 & 40 & 2.000 & 40 \\
200 & 4 & 200 & 4 \\
\hline
\end{tabular}




\section{Hasil dan Pembahasan}

\section{Senyawa Bioaktif Sarcophyton sp.}

Senyawa bioaktif Sarcophyton sp. diperoleh dengan cara ekstraksi. Ekstrak yang diperoleh ditimbang untuk mengetahui rendemennya. Rendemen dari tiap-tiap ekstrak karang lunak Sarcophyton sp. yang difragmentasi dan tidak difragmentasi ditunjukkan pada Gambar 1.

Hasil ekstraksi (Gambar 1) menunjukkan bahwa rendemen tertinggi pada ekstrak karang lunak tersebut adalah ekstrak metanol (polar) sedangkan rendemen ekstrak terkecil diperoleh dari pelarut heksana (nonpolar). Kelarutan zat pada suatu pelarut sangat ditentukan oleh kemampuan zat tersebut membentuk ikatan hidrogen (Khopkar, 2003). Metanol merupakan pelarut berbobot molekul rendah yang dapat membentuk ikatan hidrogen sehingga dapat larut dan bercampur dengan air hingga kelarutan yang tak terhingga (Hart, 1987) sehingga zat bioaktif yang terdapat pada karang lunak Sarcophyton sp. yang difragmentasi dan tidak difragmentasi lebih mudah larut dalam metanol dari pada di dalam heksana.

\section{Aktivitas Antibakteri}

Uji aktivitas antibakteri dilakukan terhadap empat bakteri uji, yang mewakili bakteri Gram negatif dan bakteri Gram positif. Hasil uji aktivitas antibakteri ekstrak Sarcophyton sp. yang difragmentasi dan tidak difragmentasi ditunjukkan pada Tabel 2 .

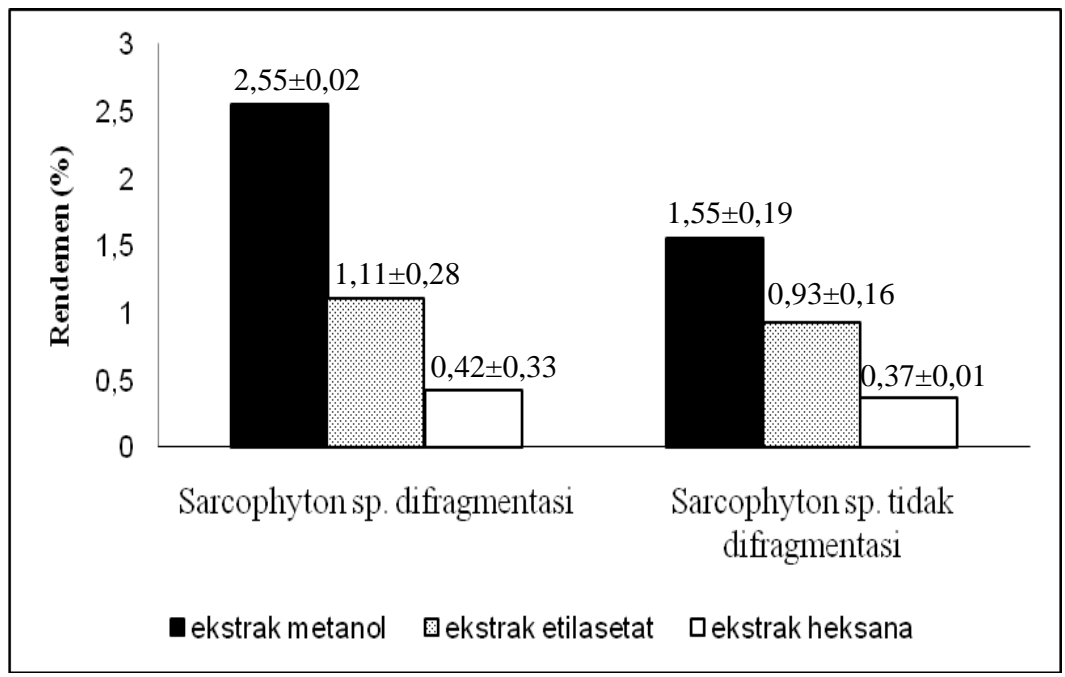

Gambar 1. Rendemen ekstrak karang lunak Sarcophyon sp. yang difrangmentasi dan tidak difragmentasi.

Tabel 2. Aktivitas antibakteri ekstrak karang lunak Sarcophyton sp. yang difragmentasi dan tidak difragmenasi pada konsentrasi $20 \mu \mathrm{g} / \mathrm{ml}$.

\begin{tabular}{clcccc}
\hline \multirow{2}{*}{ Karang Lunak } & \multirow{2}{*}{ Bakteri } & \multicolumn{4}{c}{ Diameter Zona Hambat (mm) } \\
\cline { 3 - 6 } & & $\begin{array}{c}\text { Ekstrak } \\
\text { Metanol }\end{array}$ & $\begin{array}{c}\text { Ekstrak } \\
\text { Etil Asetat }\end{array}$ & $\begin{array}{c}\text { Ekstrak } \\
\text { Heksana }\end{array}$ & $\begin{array}{c}\text { Kontrol } \\
\text { (Kloramfenikol) }\end{array}$ \\
\hline \multirow{2}{*}{ Sarcophyton yang tidak difragmentasi } & E. coli & 1 & 3 & - & 14 \\
& S. aureus & 1 & 2 & 0,75 & 19 \\
& B. cereus & 1,5 & 2 & 0,5 & 24 \\
& P. aeruginosa & 3,5 & 5,75 & 1 & 11 \\
Sarcophyton yang difragmentasi & E. coli & 0,5 & 1 & - & 14 \\
& S. aureus & 1 & 1,5 & 0,5 & 19 \\
& B. cereus & 1 & 1,5 & - & 24 \\
& P. aeruginosa & - & - & - & 11 \\
\hline
\end{tabular}


Berdasarkan Tabel 2 diketahui bahwa ekstrak etil asetat karang lunak Sarcophyton sp. yang difragmentasi dan tidak difragmentasi memiliki diameter penghambatan terbesar dibanding ekstrak lainnya. Aktivitas antibakteri ekstrak etil asetat karang lunak Sarcophyton sp. yang difragmentasi dan tidak difragmentasi tergolong kategori lemah (diameter zona hambat $<5 \mathrm{~mm}$ ), kecuali aktivitas antibakteri ekstrak Sarcophyton sp. yang tidak difragmentasi terhadap bakteri P.aeruginosa tergolong kategori sedang (diameter zona hambat 5-10 mm). Menurut Davis dan Stout (1971), ketentuan kekuatan antibiotik-antibakteri sebagai berikut: daerah hambatan $20 \mathrm{~mm}$ atau lebih berarti sangat kuat, daerah hambatan 10-20 mm (kuat), daerah hambatan 5-10 $\mathrm{mm}$ (sedang), dan daerah hambatan $5 \mathrm{~mm}$ atau kurang (lemah).

Tingginya aktivitas ekstrak etil asetat dikarenakan senyawa bioaktif yang terkandung pada ekstrak beragam dengan kelarutan yang berbeda-beda. Etil asetat merupakan pelarut semi polar yang memiliki dua sifat kelarutan, yaitu hidrofilik dan lipofilik, sehingga ekstrak yang dihasilkan memiliki polaritas yang optimum (Parhusip, 2006). Menurut Kanazawa et al., (1995), suatu senyawa yang mempunyai polaritas optimum akan mempunyai aktivitas antimikroba maksimum, karena interaksi suatu senyawa antibakteri dengan bakteri diperlukan keseimbangan hidrofilik dan lipofilik.

Kloramfenikol sebagai antibakteri kontrol mampu menghambat keempat bakteri uji dan menghasilkan zona hambat lebih besar daripada ekstrak karang lunak Sarcophyton sp. yang difragmentasi dan tidak difragmentasi. Kloramfenikol merupakan senyawa antibakteri yang stabil dan berdifusi dengan baik dalam pembenihan agar (Jawetz et al., 1996).

\section{Minimum Inhibitory Concentration (MIC)}

Nilai MIC dari ekstrak etil asetat Sarcophyton sp. yang difragmentasi dan tidak difragmentasi diketahui dengan melakukan uji MIC. Metode yang digunakan dalam pengujian MIC adalah metode difusi agar (agar diffusion method). Hasil uji MIC dari ekstrak etil asetat Sarcophyton sp. yang difragmentasi dan tidak difragmentasi (Tabel 3).

Tabel 3 menunjukkan bahwa ekstrak etil asetat Sarcophyton sp. yang tidak difragmentasi mempunyai nilai MIC terhadap bakteri E.coli, S.aureus, dan B.cereus adalah $300 \mu \mathrm{g} /$ disk, sedangkan terhadap P.aeruginosa $240 \mu \mathrm{g} /$ disk. Nilai MIC ekstrak etil asetat Sarcophyton sp. yang difragmentasi terhadap bakteri E. coli, $S$. aureus, dan B. cereus masing-masing sebesar $480 \mu \mathrm{g} / \mathrm{disk}, 420 \mu \mathrm{g} / \mathrm{disk}$, dan $420 \mu \mathrm{g} /$ disk., sedangkan bakteri P.aeruginosa tidak terhambat pertumbuhannya pada selang konsentrasi ekstrak yang digunakan. Kloramfenikol mempunyai nilai MIC terhadap S.aureus dan E. coli, $B$. cereus, dan $P$. aeruginosa sebesar $4 \mu \mathrm{g} /$ disk.

Faktor yang memengaruhi nilai minimum Inhibitory Concentration (MIC) adalah jenis organisme, ukuran inokulum, komponen medium kultur, waktu inkubasi, serta kondisi inkubasi berupa suhu dan $\mathrm{pH}$ (Schegel dan Schmidt, 1994).

\section{Tingkat Toksisitas dengan Metode Brine Shrimp Lehal Test (BSLT)}

Uji toksisitas dilakukan untuk mengetahui pada konsentrasi berapa ekstrak etil asetat Sarcophyton sp. yang difragmentasi dan tidak difragmentasi bersifat toksik terhadap hewan uji yang digunakan yaitu Artemia salina. Data hasil uji toksisitas (BSLT) terlihat pada Tabel 4.

Tabel 4 menunjukkan hasil analisis uji BSLT terhadap ekstrak kasar karang lunak Sarcophyton sp. difragmentasi dan tidak difragmentasi. Berdasarkan data tersebut semakin tinggi konsentrasi yang diujikan semakin banyak A. salina yang mati. Nilai $\mathrm{LC}_{50}$ (konsentrasi yang dapat menyebabkan kematian $50 \%$ A. salina) dapat diperoleh dengan menggunakan analisis probit dan persamaan regresi. Gambar 2 menunjukkan grafik kematian A. salina (hubungan antara log konsentrasi dengan mortalitas).

Berdasarkan Gambar 2 diperoleh persamaan regresi hubungan antara log konsentrasi dan mortalitas A. salina dari ekstrak etil asetat Sarcophyton sp. difragmentasi dan tidak difragmentasi, yaitu $\mathrm{Y}=0,84 \mathrm{X}+3,1733$ (Gambar 2a) dan Y=1,11X+3,1633 (Gambar 2b) sehingga diperoleh nilai $\mathrm{LC}_{50}$ ekstrak etil asetat Sarcophyton sp. difragmentasi dan tidak difragmentasi yang dihasilkan dari perhitugan, masing-masing sebesar $149,50 \mathrm{ppm}$ dan 45,15 ppm. Nilai tersebut menunjukkan bahwa ekstrak etil asetat Sarcophyton sp. difragmentasi dan 
tidak difragmentasi termasuk dalam kategori toksik. Beberapa hasil penelitian terhadap senyawa bioaktif yang diuji dengan $A$. salina (BSLT) menunjukkan adanya korelasi spesifik terhadap uji antikanker bila mempunyai $\mathrm{LC}_{50}<1000 \mathrm{ppm}$. Hal ini didukung hasil penelitian Wikanta et al., (2007) menunjukkan bahwa ekstrak kasar, fraksi metanol, dan fraksi etil asetat karang lunak Sarcophyton glaucum dapat menghambat sel lestari tumor HeLa dengan nilai $\mathrm{LC}_{50}$ masing-masing sebesar 25,12 ; 50,12 dan $31,62 \mu \mathrm{g} / \mathrm{ml}$.

\section{Uji Fitokimia}

Uji fitokimia ini dilakukan untuk menentukan ciri senyawa yang terdapat pada suatu bahan yang mempunyai efek racun atau efek yang bermanfaat, ditunjukkan oleh ekstrak kasar bila diuji dengan sistem biologi (Harborne, 1987). Kandungan senyawa kimia yang terdapat pada ekstrak etil asetat Sarcophyton sp. yang difragmentasi dan tidak difragmentasi terpilih dapat dilihat pada Tabel 5.

Hasil uji fitokimia menunjukkan bahwa ektrak etil asetat Sarcophyton sp. yang difragmentasi dan tidak difragmentasi memiliki kandungan bioaktif yang berbeda. Perbedaan kandungan senyawa bioaktif tersebut diduga disebabkan oleh pengaruh fragmentasi dan perbedaan kondisi lingkungan sehingga memengaruhi produksi senyawa bioaktif karang lunak tersebut. Dugaan tersebur berdasarkan hasil laporan Coll dan Sammarco (1983) yang menunjukkan bahwa senyawa metabolit sekunder memiliki peranan penting dalam adaptasi tingkah laku yang beraneka ragam dan interaksi ekologinya dengan sejumlah organisme laut lainnya.

Tabel 3. Aktivitas ekstrak etil asetat Sarcophyton sp. dan kontrol pada uji MIC.

\begin{tabular}{|c|c|c|c|c|}
\hline \multirow{2}{*}{$\begin{array}{c}\text { Konsentrasi Ekstrak Etil Asetat Sarcophyton yang } \\
\text { Tidak Difragmentasi ( } \mu \mathrm{g} / \mathrm{disk})\end{array}$} & \multicolumn{4}{|c|}{ Diameter Zona Hambat (mm) } \\
\hline & E.coli & S.aureus & B.cereus & P.aeruginosa \\
\hline 480 & 3 & 4 & 4 & 6 \\
\hline 420 & 2 & 2,5 & 2,5 & 5,75 \\
\hline 360 & 1,5 & 2 & 2 & 4,5 \\
\hline 300 & 1 & 2 & 1 & 4 \\
\hline 240 & - & - & - & 3,5 \\
\hline 180 & - & - & - & - \\
\hline 40 & - & - & - & - \\
\hline 4 & - & - & - & - \\
\hline Konsentrasi Ekstrak & \multicolumn{4}{|c|}{ Diameter Zona Hambat (mm) } \\
\hline Etil Asetat Sarcophyton yang Difragmentasi ( $\mu \mathrm{g} / \mathrm{disk})$ & E.coli & S.aureus & B.cereus & P.aeruginosa \\
\hline 480 & 1 & 3 & 3,5 & - \\
\hline 420 & - & 1,5 & 1,5 & - \\
\hline 360 & - & - & - & - \\
\hline 300 & - & - & - & - \\
\hline 240 & - & - & - & - \\
\hline 180 & - & - & - & - \\
\hline 40 & - & - & - & - \\
\hline 4 & - & - & - & - \\
\hline \multirow[t]{2}{*}{ Konsentrasi Kontrol (kloramfenikol) ( $\mu \mathrm{g} /$ disk) } & \multicolumn{4}{|c|}{ Diameter Zona Hambat (mm) } \\
\hline & E.coli & S.aureus & B.cereus & P.aeruginosa \\
\hline 480 & 30 & 22 & 24 & 22 \\
\hline 420 & 23 & 20 & 23 & 22 \\
\hline 360 & 20 & 19 & 21 & 21 \\
\hline 300 & 20 & 19 & 20 & 11 \\
\hline 240 & 19 & 19 & 20 & 11 \\
\hline 180 & 19 & 18 & 18 & 11 \\
\hline 40 & 10 & 17 & 17 & 11 \\
\hline 4 & 5 & 5 & 9 & 10 \\
\hline
\end{tabular}


Tabel 4. Data hasil uji toksisitas (BSLT) ekstrak etil asetat Sarcophyton sp. difragmentasi dan tidak difragmentasi.

\begin{tabular}{cccccc}
\hline Ekstrak Etil Asetat & $\begin{array}{c}\text { Konsentrasi } \\
(\mathbf{p p m})\end{array}$ & $\begin{array}{c}\text { Log } \\
\text { Konsentrasi }\end{array}$ & $\begin{array}{c}\text { Persen } \\
\text { Mortalitas }\end{array}$ & $\begin{array}{c}\text { Probit } \\
(\mathbf{y})\end{array}$ & $\begin{array}{c}\text { LC 50 } \\
(\mathbf{p p m})\end{array}$ \\
\hline \multirow{2}{*}{ Sarcophyton sp. tidak difragmentasi } & 10 & 1 & 20 & 4,16 & 4,48 \\
& 100 & 2 & 30 & 60 & 5,15 \\
& 1000 & 3 & 13,33 & 5,08 & \\
Sarcophyton sp. yang difragmentasi & 10 & 1 & 20 & 4,48 & 149,50 \\
& 100 & 2 & 53,33 & 3,87 & \\
\hline
\end{tabular}

Tabel 5. Hasil identifikasi kandungan fitokimia karang lunak Sarcophyton sp. yang difragmentasi dan tidak difragmentasi.

\begin{tabular}{|c|c|c|c|}
\hline \multirow[b]{2}{*}{ Uji Fitokimia } & \multicolumn{2}{|c|}{ Hasil uji (warna) } & \multirow[b]{2}{*}{ Standar (warna) } \\
\hline & $\begin{array}{l}\text { Sarcophyton yang } \\
\text { tidak difragmentasi }\end{array}$ & $\begin{array}{l}\text { Sarcophyton yang } \\
\text { difragmentasi }\end{array}$ & \\
\hline \multicolumn{4}{|l|}{ a. Alkaloid } \\
\hline - Wagner & $(-)$ & $(-)$ & Endapan coklat \\
\hline - Meyer & $(+)$ & $(-)$ & Endapan putih kekuningan \\
\hline - Dragendorf & $(-)$ & $(-)$ & Endapan merah sampai jingga \\
\hline b. Steroid/Triterpenoid & $(+++)$ & $(++)$ & Merah $\rightarrow$ biru atau hijau \\
\hline c. Flavonoid & $(++++)$ & $(++)$ & $\begin{array}{l}\text { Merah, kuning/ jingga pada amil lapisan amil } \\
\text { alkohol }\end{array}$ \\
\hline d. Saponin (uji busa) & $(-)$ & $(-)$ & Terbentuk busa stabil selama 30 menit \\
\hline e. Fenol hidrokuinon & $(-)$ & $(-)$ & Hijau / hijau biru \\
\hline f. Molisch & $(-)$ & $(-)$ & Ungu \\
\hline g. Benedict & $(-)$ & $(-)$ & Hijau, kuning / merah bata \\
\hline h. Biuret & $(-)$ & $(-)$ & Ungu \\
\hline i. Ninhidrin & $(-)$ & $(-)$ & Biru \\
\hline
\end{tabular}

Keterangan : (+ + + +): Sangat kuat; $(+++)$ Kuat; $(++)$ Sedang; (+) Lemah;(-) Tidak ada

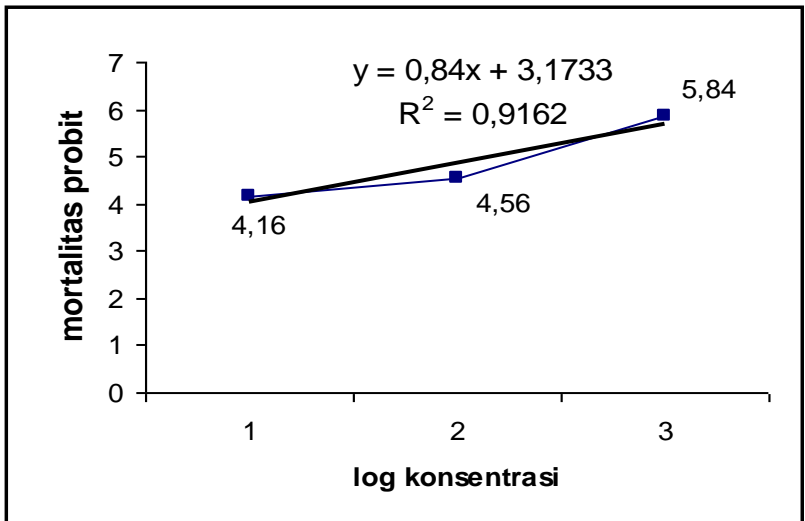

$\mathbf{a}$

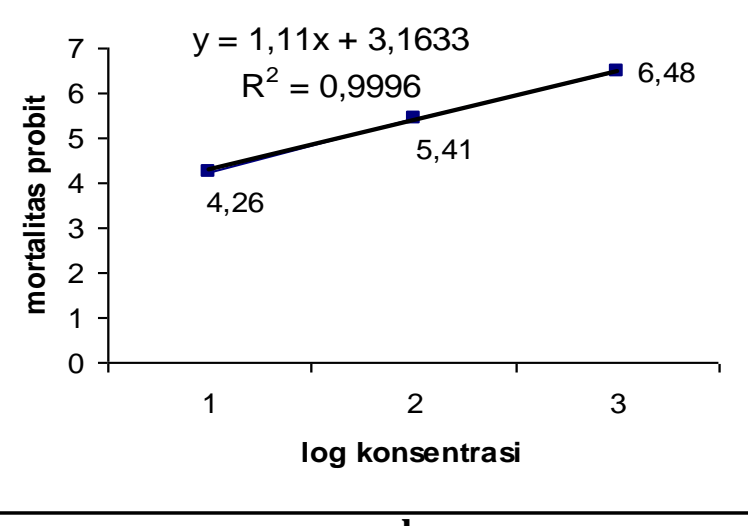

b

Gambar 2. Hubungan antara log konsentrasi dan mortalitas ekstrak etil asetat Sarcophyton sp. yang (a) difragmentasi dan (b) tidak difragmentasi.

\section{Simpulan dan Saran}

\section{Simpulan}

Pelarut yang menghasilkan rendemen terbesar adalah methanol. Ekstrak etil asetat karang lunak jenis Sarcophyton sp. yang difragmentasi dan tidak difragmentasi menunjukkan aktivitas antibakteri terbaik dengan aktivitas antibakteri ekstrak yang masih tergolong lemah. Ekstrak etil asetat Sarcophyton sp. yang tidak difragmentasi mempunyai nilai MIC terbaik pada bakteri P.aeruginosa sebesar $240 \mu \mathrm{g} / \mathrm{disk}$, sedangkan nilai MIC terbaik ekstrak etil asetat Sarcophyton sp. yang difragmentasi terhadap bakteri $S$. aureus dan B. cereus 420 $\mu \mathrm{g} /$ disk. Tingkat toksisitas ekstrak etil asetat Sarcophyton sp. yang difragmentasi dan tidak difragmentasi termasuk kategori toksik dan berpotensi sebagai antikanker, memiliki $\mathrm{LC}_{50}<$ $1000 \mathrm{ppm}$. 


\section{Saran}

Perlu dilakukan penelitian uji aktivitas antibakteri terhadap karang lunak Sarcophyton sp. hasil fragmentasi pada berbagai umur panen, sehingga akan diketahui pada umur panen berapa karang lunak ini mempunyai aktivitas antibakteri yang mendekati karang lunak Sarcophyton sp. yang tidak difragmentasi. Perlu dilakukan pemisahan dan pemurnian tiap-tiap komponen dari ekstrak Sarcophyton sp. yang difragmentasi dan tidak difragmentasi.

\section{Daftar Pustaka}

Astuti, P., Alam, G., Pratiwi, S.U.T., Hertani, T. dan Wahyuono, S. 2003. Skrining Senyawa Antiinfeksi dari Spons yang Dikoleksi dari Bunaken Manado. Biota, VIII (2): 47-52.

Badria, F.A., Guirguis, A.N., Perovic, S., Steffen, R., Muller, W.E.G. dan Schroder, H.C. 1998. Sarcophytolide: a New Neuroprotective Compound from Soft Coral Sarcophyton glaucum. Toxicology, 131 (3): 133-143.

Carballo, J.L., Hernadez-Inda, Z.L., Perez, P. dan GarciaGravalos, M.D. 2002. A comparison Between Two Brine Shrimp Assays to Detect in Vitro Cytotoxicity in Marine Natural Product (methodology article). Bioorganic Marine Chemistry Biotechnology, 2: 1-5.

Coll, J.C. dan Sammarco, P.W. 1983. Terpenoid Toxins of Soft Corals (Cnidaria, Octocorallia) their Nature, Toxicity and Ecological Significance. Toxicol Suppl, 41 (3): 69-72.

Davis, W.W. dan Strout, T.R. 1971. Disc Plate Method of Microbiological Antibiotic Assay. $J$. Microbiology, 22 (4): 666-670.

Harborne, J.B. 1987. Metode Fitokimia. Padmawinata K, Soediro I, penerjemah. Bandung: ITB. Terjemahan dari : Phytochemical Methods.

Hart, H. 1987. Kimia Organik. Suatu Kuliah Singkat. S. Achmadi, penerjemah Jakarta: Erlangga. Terjemahan dari: Organic Chemistry.

Huda, A.W.N., Munira, M.A.S., Fitrya, S.D. dan Salmah, M. 2009. Antioxidant activity of Aquilaria malaccensis (thymelaeaceae) leaves. Reasearch Article, 1 (5): 270-273.

Jawetz, E., Melnick, J. dan Adelberg, E. 1996. Mikrobiologi Kedokteran. Ed ke-20. Nugroho, E., Maulany, R.F., penerjemah. Jakarta: EGC. Terjemahan dari: Medical Microbiology.

Kanazawa, A., Ikeda, T. dan Endo, T. 1995. A Novel Approach to Mode of Action of Cationic Biocides Morphological Effect on Antibacterial Activity. J. of Applied Bacteriology, 78 (1): 56-60.
Khopkar, S.M. 2003. Konsep Dasar Kimia Analitik. Jakarta: UI-Press.

Lopez, J.L., McLaughlin, J.E. dan Anderson. 1993. Antimicrobial activity of medicinal plant extract against foodborne spoilage and pathogenic microorganism. National science, 37 (1): 460-467.

McLaughlin, J.L., Rogers, L.L. dan Anderson, J.E. 1998. The use of Biological Assay to Evaluate Botanicals. J. Drugs Information, 32: 13-517.

Meyer, B.N., Ferrigni, N.R., Putnam, J.E., Jacobsen, L.B., Nicholas, D.E. dan McLaughlin, J.L. 1982. Brine shrimp: a convenient general bioassay for active plant constituents. Planta Medica, 45 (3): 31-34.

Noer, I.S. dan Nurhayati, L. 2006. Bioaktivitas Ulva reticulata Forsskal asal Gili Kondo Lombok Timur terhadap bakteri. Biotika, 5 (1): 45-60.

Parhusip, A.J.N. 2006. Kajian Mekanisme Antibakteri Ekstrak Andaliman (Zanthoxylum acanthopodium DC) terhadap Bakteri Pathogen Pangan. Disertasi. Bogor: Sekolah Pasca Sarjana, Institut Pertanian Bogor.

Priyatmoko, W. 2008. Aktivitas antibakteri karang lunak hasil transplantasi (Sinularia sp.) pada dua kedalaman berbeda di Perairan Pulau Pramuka, Kepulauan Seribu, DKI Jakarta [skripsi]. Bogor: Fakultas Perikanan dan Ilmu Kelautan, Institu Pertanian Bogor.

Sawant, S., Youssef, D., Mayer, A., Sylvester, P., Wali, V. dan Arant, M.S.K.El. 2006. Anticancer and Anti-inflammatory Sulfur-containing Semisynthetic Derivatives of Sarcophine. Chem. Pharm. Bull., 54: 1119-1123.

Schlegel, H.G. dan Schmidt, K. 1994. Mikrobiologi umum. Baskara T, Penerjemah. Yogyakarta: Gajah Mada University Press.

Smith, L.D. dan Hughes, T.P. 1999. An experimental assessment of survival, re-attachment and fecundity of coral fragments. J. Exp. Mar. Bio. and Ecol., 235 (1): 147-164.

Soedharma, D., Kawaroe, M. dan Haris, A. 2005. Kajian Potensi Bioaktif Karang Lunak (Octocorallia; Alcyonacea) di Perairan Kepulauan Seribu, DKI Jakarta. J. Ilmu-ilmu Perairan dan Perikanan Indonesia, (2): 121-128.

Triyulianti, I. 2009. Bioaktivitas ekstrak karang lunak Sinularia sp. dan Lobophytum sp. hasil fragmentasi di Perairan Pulau Pramuka, Kepulauan Seribu, DKI Jakarta [tesis]. Bogor: Sekoah Pasca Sarjana, Institut Pertanian Bogor.

Wikanta, T., Zakaria, Y.A., Ratih, D. dan Nusrid, M. 2007. Uji Aktivitas Sitotoksik Ekstrak Karang Lunak Sarcophyton glaucum (Quoy dan Gaimard) terhadap Sel Lestari Tumor HeLa. J. Pascapanen dan Bioteknologi Kelautan dan Perikanan, 2 (1): 69-80. 